\title{
P-doped mesoporous carbons for high-efficiency electrocatalytic oxygen reduction
}

\author{
Hui Zhao a,b, Zhong-Pan Hu a,b, Yun-Pei Zhu a a,b, Li Ge a,b, Zhong-Yong Yuan a,b,* \\ a National Institute for Advanced Materials, School of Materials Science and Engineering, Nankai University, Tianjin 300350, China \\ ${ }^{\mathrm{b}}$ Key Laboratory of Advanced Energy Materials Chemistry (Ministry of Education), Collaborative Innovation Center of Chemical Science and Engineering \\ (Tianjin), Nankai University, Tianjin 300071, China
}

\section{A R T I C L E I N F O}

\section{Article history:}

Received 17 March 2019

Accepted 1 April 2019

Published 5 September 2019

\section{Keywords:}

P-doping

Mesoporous carbons

Electrocatalyst

Oxygen reduction reaction

\begin{abstract}
A B S T R A C T
Chemically modified carbonaceous materials have attained utmost attention in the fields of renewable energy storage and conversion, due to the controllable physicochemical properties, tailorable micro-/nanostructures, and respectable stability. Herein, P-doped mesoporous carbons were synthesized by using F127 as the soft template, organophosphonic acid as the P source and phenolic resin as the carbon source. Small amounts of iron species were introduced to act as a graphitization catalyst. The synthesized carbons exhibit the well-defined wormhole-like pore structure featuring high specific surface area and homogenously doped P heteroatoms. Notably, introducing iron species during the synthesis process can optimize the textural properties and the degree of graphitization of carbon materials. The doping amount of $\mathrm{P}$ has an important effect on the porous structure and the defect degree, which correspondingly influence the active sites and the oxygen reduction reaction (ORR) activity. The resultant material presents superior catalytic activity for the ORR, together with remarkably enhanced durability and methanol tolerance in comparison with the commercial Platinum catalyst, demonstrating the possibility for its use in electrode materials and electronic nanodevices for metal-air batteries and fuel cells.
\end{abstract}

(C) 2019, Dalian Institute of Chemical Physics, Chinese Academy of Sciences. Published by Elsevier B.V. All rights reserved.

\section{Introduction}

Sustainable energy storage and conversion devices like rechargeable metal-air batteries and fuel cells have recently attracted significant interest due to the high energy density and considerable efficiency. Noticeably, the oxygen reduction reaction (ORR) at the cathode is kinetically sluggish, which is one of the bottlenecks that greatly restrict the extensive application of these devices [1]. Traditionally, precious Pt and corresponding derivatives are employed to realize impressive electrochemical activity together with high current density and low overpotential [2-5], though the scarcity, susceptibility to time-dependent potential drift, and easy poisoning by $\mathrm{CO}$ and methanol impede their applicability and availability [6-8]. Therefore, exploring readily available and sustainable alternatives to replace Pt-based noble electrocatalysts towards efficient ORR is urgently needed for the development of high-performance energy-related devices.

Within this context, considerable efforts have been dedicated in developing earth-abundant transition-metal-based and metal-free catalysts, among which carbon-based nanomaterials, containing carbon nanotubes, porous carbons and graphene, have been emerging as promising electrocatalysts owing to the distinct advantages of low cost, long-term stability,

\footnotetext{
* Corresponding author. Tel: +86-20-23509610; E-mail: zyyuan@nankai.edu.cn

This work was supported by the National Natural Science Foundation of China $(21421001,21573115)$.

DOI: S1872-2067(19)63363-2 | http://www.sciencedirect.com/science/journal/18722067 | Chin. J. Catal., Vol. 40, No. 9, September 2019
} 
tunable surface properties, and sufficient electron conductivity [9-14]. Furthermore, doping heteroatom (e.g., N, P, B, S) into carbon frameworks can significantly improve the catalytic activity of carbon materials, as the dopant atoms can break the electroneutrality of nearby carbons and thus create the active sites, favoring the adsorption of $\mathrm{O}_{2}$ molecules and the subsequent oxygen reduction process [15-20]. Indeed, various $\mathrm{N}$-doped carbons, such as graphene sheets, carbon nanotubes, mesoporous carbon and nanoshell carbons have been successfully fabricated and presented high electrocatalytic activities for ORR [21-24]. In contrast, P-doping has been reported that it can modify the structure and performance more effectively because of the larger covalent radius and lower electronegativity of P compared with $\mathrm{N}$ counterpart, such as P-doped mesoporous carbon, microporous carbon, and graphite layers exhibiting improved ORR activity [25-30]. On the other hand, the ORR electrocatalytic activity is greatly dependent on the structural properties of carbons, which determines the conductivity, stability and dispersion degree of active sites of the catalyst [31]. On this consideration, constructing porous carbons with high specific surface areas along with well-developed porosity should be favorable to the efficient utilization of active sites and the improvement of mass transfer. A variety of state-of-the-art techniques have been employed to synthesize P-doped mesoporous carbons, for instance, pyrolysis of toluene and triphenylphosphine at $1000{ }^{\circ} \mathrm{C}$ under $\mathrm{Ar}$ atmosphere [25], nanocasting method using SBA-15 as template [32]. However, these methods often involve complex and hazardous synthesis processes. Previously, we fabricated P-doped mesoporous carbons using soft-templating method with organophosphonic acid as the P source [27]. The resultant material inherits high P doping levels and large surface areas, ensuring the promising ORR performance, but the apparent activity is still not satisfactory to compete with commercial $\mathrm{Pt} / \mathrm{C}$ catalyst.

In this work, we report that it is feasible to derive P-doped mesoporous carbons by simply adding small amounts of iron with the assistance of organophosphonic acids. Fe species originating from $\mathrm{FeCl}_{3}$ act as graphitization catalysts that can be removed completely by acid washing. The resultant carbons feature high surface area, narrow pore size distributions, and good conductivity, which empower them to achieve superior electrocatalytic performance. In addition, the effect of doping amount of $\mathrm{P}$ on the mesoporous carbons was also investigated in detail. It found that the P-MC-4 exhibited impressive electrocatalytic performance, long-term stability together with superb methanol tolerance. The results can provide new insights into the highly efficient construction of metal-free heteroatom-doped mesoporous carbons with intriguing textural characters.

\section{Experimental}

\subsection{Materials synthesis}

In a typical procedure, $0.2 \mathrm{mmol}$ F127 and $20 \mathrm{mmol}$ resorcinol were dissolved in a mixed solution of water/ethanol with a volume ratio of 1:1 at room temperature. After stirring for 1 $h$, a colorless solution was obtained. Then a desired amount of HEDP was introduced to the above mixture with further stirring of $1 \mathrm{~h}$, followed by dropwised addition of $2.5 \mathrm{mmol}$ formaldehyde solution under vigorous stirring. Thereafter, 1 mmol $\mathrm{FeCl}_{3}$ was introduced, and the reaction solution was further stirred for another $1 \mathrm{~h}$. The above mixture was then transferred to an autoclave and aged at $80{ }^{\circ} \mathrm{C}$ for $2 \mathrm{~d}$. The red-brown bulk product was obtained by filtration, washed with ethanol and water for three times, and dried at $80{ }^{\circ} \mathrm{C}$ overnight. The dried bulk product was then carbonized under $\mathrm{N}_{2}$ atmosphere at $350{ }^{\circ} \mathrm{C}$ for $2 \mathrm{~h}$ with a ramp of $4{ }^{\circ} \mathrm{C} \mathrm{min}-1$ and $900{ }^{\circ} \mathrm{C}$ for $2 \mathrm{~h}$ with a ramp rate of $5{ }^{\circ} \mathrm{C} \mathrm{min}^{-1}$. The calcined bulk was washed by concentrated $\mathrm{HNO}_{3}$ for several times to remove iron species. The obtained powder was denoted as P-MC- $x$, wherein $x$ denotes as the molar ratio of $\mathrm{P}$ to Fe, i.e., $x=4,6$, 8. P-doped mesoporous carbon (marked as P-MC) was prepared via the similar processes in the absence of $\mathrm{FeCl}_{3}$. The undoped mesoporous carbon (marked as MC) was also prepared without the addition of $\mathrm{HEDP}$ and $\mathrm{FeCl}_{3}$.

\subsection{Physicochemical characterization}

X-ray diffraction (XRD) patterns were obtained on a Bruker D8 Focus diffractometer with $40 \mathrm{kV}$ operation voltage and current at $40 \mathrm{~mA}$ using $\mathrm{Cu}-K_{\alpha}$ radiation $(\lambda=0.15418 \mathrm{~nm})$. Raman analysis was performed on a Thermo-Fisher Scientific DXR spectrometer (514 $\mathrm{nm}$ radiation laser). $\mathrm{N}_{2}$ sorption experiments were undertaken on a Quantachrome NOVA2000e automated surface area analyzer isothermally at $-196{ }^{\circ} \mathrm{C}$. Before the measurement, the samples were all degassed at $200{ }^{\circ} \mathrm{C}$ overnight. The specific area was determined by the Brunanuer-Emmett-Teller (BET) method and total pore volume was determined from the amount of the $\mathrm{N}_{2}$ adsorbed at a relative pressure of 0.98 . The pore size distributions were calculated from the adsorption branch using Barrett-Joyner-Halenda (BJH) method. The scanning electron microscopy (SEM) was performed on a Jeol JSF-7500L microscopy. X-ray photoelectron spectroscopy (XPS) was performed for the surface analysis of the synthesized materials, using a Kratos Axis Ultra DLD spectrometer with $\mathrm{Al}-K_{\alpha}$ irradiation $(1486.6 \mathrm{eV})$.

\subsection{Electrochemical measurements}

The electrocatalytic ORR activity of the samples was investigated with the rotating disk electrode (RDE) technique using WaveDriver 20 bipotentiostat/galvanostat electrochemical workstation (Pine Research Instrumentation) under room temperature. A typical three-electrode electrochemical cell was used, wherein the catalyst film-coated glassy carbon disks were utilized as the working electrode. $\mathrm{Ag} / \mathrm{AgCl}(3 \mathrm{~mol} / \mathrm{L} \mathrm{KCl})$ and $\mathrm{Pt}$ foil were used as the reference and counter electrodes, respectively.

For preparing the working electrode, $5 \mathrm{mg}$ of samples were dispersed in $1 \mathrm{~mL}$ Mill-Q water under sonication to form a homogenous ink. $10 \mu \mathrm{L}$ of the dispersion was drop casted onto a polished $5 \mathrm{~mm}$-diameter glassy carbon electrode. After drying at room temperature overnight, $5 \mu \mathrm{L}$ of Nafion solutions $[0.5$ 
wt\%) was dropped on the surface of electrode and allow to dry, and the resultant electrode served as a working electrode. For the ORR test, Before the ORR measurement, the electrolyte (0.1 $\mathrm{M} \mathrm{KOH}$ ) was ventilated with $\mathrm{O}_{2}$ for 30 min to ensure $\mathrm{O}_{2}$ saturation. Cyclic voltammetry (CV) curves were measured at a scanning rate of $20 \mathrm{mV} \mathrm{s}^{-1}$ within the potential range from -1.0 to $+0.2 \mathrm{~V}(\mathrm{vs} . \mathrm{Ag} / \mathrm{AgCl}$ ). For linear sweep voltammetry (LSV) tests, the potential was varied between -1.0 and $0.2 \mathrm{~V}(\mathrm{vs} . \mathrm{Ag} / \mathrm{AgCl})$ with a scan rate of $10 \mathrm{mV} \mathrm{s}^{-1}$. The number of electron transfer can be calculated from the Koutechy-Levich (K-L) equation:

$$
\begin{gathered}
J^{-1}=J_{\mathrm{L}}-1+J_{\mathrm{K}} \mathrm{K}^{-1}=\left(B \omega^{1 / 2}\right)^{-1}+J_{\mathrm{K}^{-1}} \\
B=0.62 n F C_{0}\left(D_{0}\right)^{2 / 3} \mathrm{~V}^{-1 / 6} \\
J_{\mathrm{K}}=n F k C_{0}
\end{gathered}
$$

where $J, J_{\mathrm{L}}$ and $J_{\mathrm{K}}$ is disk, diffusion-limiting and kinetic current densities, respectively. $k$ is the electron-transfer rate constant. $\mathrm{F}$ is Faraday constant $\left(96485 \mathrm{C} \mathrm{mol}^{-1}\right) . \omega$ is the electrode rotating rate. $n$ is the transferred electron number per oxygen molecule. $v$ is the kinetic viscosity $\left(0.01 \mathrm{~cm}^{2} \mathrm{~s}^{-1}\right)$. $C_{02}$ is the bulk concentration of $\mathrm{O}_{2}\left(1.2 \times 10^{-6} \mathrm{~mol} \mathrm{~cm}^{-1}\right)$. $D_{02}$ is the diffusion coefficient of $\mathrm{O}_{2}$ in $0.1 \mathrm{~mol} / \mathrm{L} \mathrm{KOH}\left(1.9 \times 10^{-1} \mathrm{~cm}^{2} \mathrm{~s}^{-1}\right)$. The constant 0.2 is adopted when the rotation speed is expressed in rpm.

\section{Results and discussion}

The pure mesoporous carbon was synthesized using a procedure similar to that reported elsewhere [33]. The procedure for synthesizing P doped mesoporous carbons included an organic-organic self-assembly coexisted with the in situ doping $\mathrm{P}$ by using HEDP through a simple autoclaving process and high-temperature carbonization under $\mathrm{N}_{2}$ atmosphere. Actually, HEDP acted as both the P source and the catalyst for promoting the polymerization of resorcinol with formaldehyde. A small amount of $\mathrm{FeCl}_{3}$ was introduced during the synthesis procedure, and the synthesized samples were marked as P-MC- $x(x=4,6,8)$. While, P-doped mesoporous carbon (marked as P-MC) was synthesized via the similar procedures in the absence of $\mathrm{FeCl}_{3}$, and the undoped mesoporous carbon (marked as MC) was also synthesized without the introduction of $\mathrm{HEDP}$ and $\mathrm{FeCl}_{3}$.

The morphology of as-prepared P-MC-4 catalyst was illustrated by electron microscopy measurements, as shown in Fig. 1(a). The resulting P-doped carbon material shows the rough and irregular surface with well-defined mesopores. TEM imag- es (Fig. 1(b) and (c)) reveals the presence of a distinct wormhole-like pore structure system with the pore size of around 6 $\mathrm{nm}$, which may facilitate the mass transportation during the catalytic process. The selected area electron diffraction (SAED) shows the mesoporous carbons possess a low graphitization degree. The P distribution on the resultant P-MC-4 was further investigated by EDS elemental mapping. As shown in Figs. 1(d) -(g), the mapping image of $P$ unveils that $P$ was uniformly distributed in the P-MC-4, confirming the successful P doping into the carbon framework.

Wide-angle XRD pattern (Fig. 2(a)) of all the carbonaceous materials shows the presence of amorphous carbon, wherein two diffraction peaks situated at approximately $2 \theta=23^{\circ}$ and $44^{\circ}$, corresponding to the (002) and (100) planes of graphite with a low graphitization degree, respectively [34]. The small-angle XRD pattern of all the prepared samples was also collected and shown in Fig. 2(b). P-doped mesoporous carbons all exhibit a diffraction peak at $0.75^{\circ}(2 \theta)$, revealing the positive role of the introduction of HEDP in facilitating the formation of well-defined wormhole-like pore structures. Intriguingly, the diffraction peak of P-MC-4 is more distinctive than that of P-MC, suggesting that $\mathrm{Fe}$ species may play an important role in enhancing the activation for carbons [35]. Additionally, the porous structure of P-MC-4 is more well-defined than both the P-MC-6 and P-MC-8. It is because the usage of high amount of $\mathrm{P}$ into the framework may distort the carbon lattice, resulting in irregular pore structure [36].

The porosity of the carbon catalysts was determined by nitrogen sorption technique. Table 1 lists the corresponding porous properties. All the samples show isotherms of type IV associated with typical H1 hysteresis loops (Fig. 2(c)), characteristics of mesoporous materials, which is in good agreement with the TEM observation. According to the reports, mesopores are beneficial to catalytic process due to the less limited diffusion of electrolyte ions (proton) into inside layers [37]. Notably, the pore size distribution of P-MC-4 (Fig. 2(d)) is narrower than other samples. The surface area of P-MC $\left(721 \mathrm{~m}^{2} \mathrm{~g}^{-1}\right)$ is much larger than that of pure carbon $\left(666 \mathrm{~m}^{2} \mathrm{~g}^{-1}\right)$, suggesting that the incorporation of $\mathrm{P}$ can improve the porous structure properties of carbons and generate abundant and accessible active sites. The surface area of P-MC-4 is $737 \mathrm{~m}^{2} \mathrm{~g}^{-1}$, which is the largest. The surface area of P-MC- 6 and P-MC- 8 decreases to 685 and $678 \mathrm{~m}^{2} \mathrm{~g}^{-1}$, respectively. It is proposed that the suitable doping amount of $\mathrm{P}$ is indispensable for the improve-

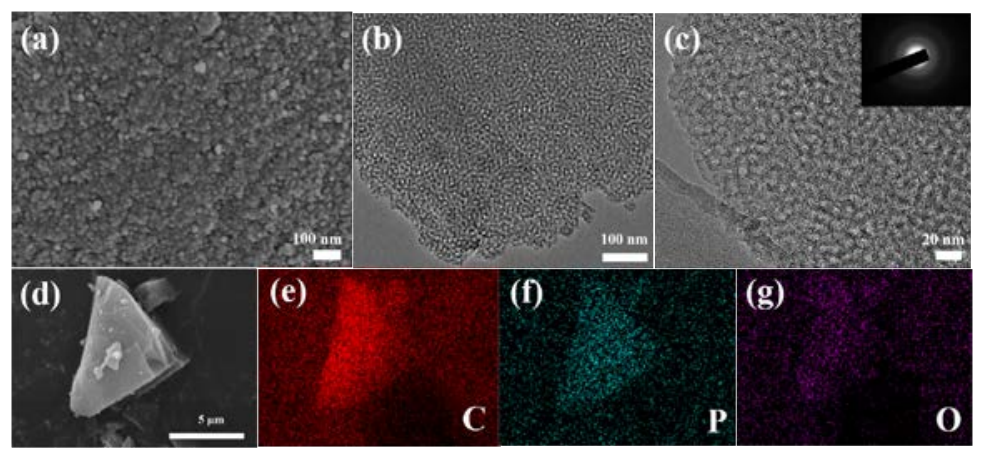

Fig. 1. SEM (a), TEM (b, c) and EDS elemental mapping (d-g) images of the P-MC-4 sample. Inset in (c) is the corresponding SAED pattern of P-MC-4. 

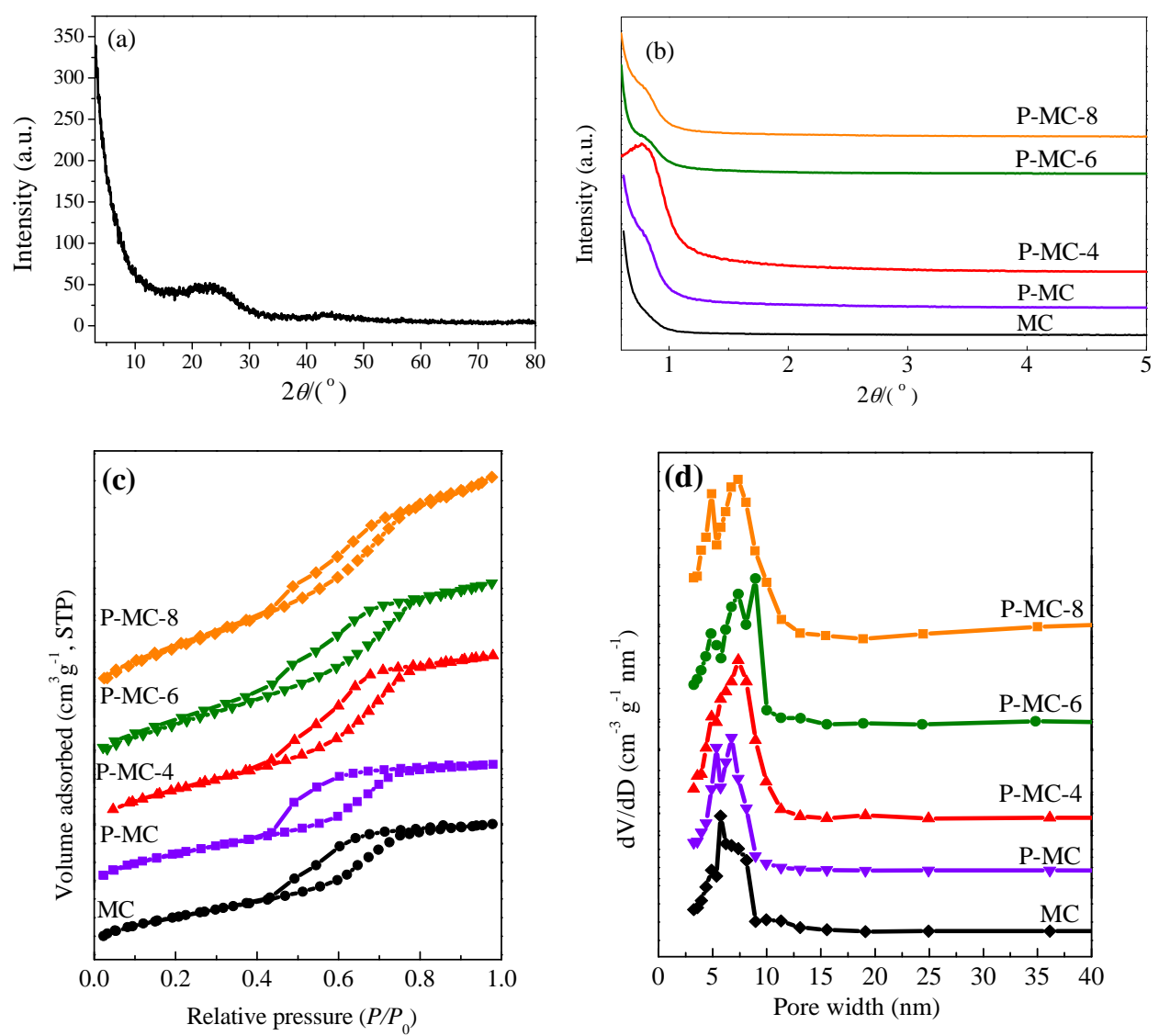

Fig. 2. Wide-angle (a) and small-angle (b) XRD patterns, nitrogen adsorption-desorption isotherms (c) and the corresponding pore size distribution curves (d) of the synthesized carbonaceous materials.

ment of porous properties. The high doping amount of P may lead to the inferior textural properties of the corresponding carbon materials.

Raman spectra were further performed to examine the graphitization degrees of the obtained carbons. As observed in Fig. 3(a), all the carbon materials show two prominent peaks centered at approximately 1348 and $1591 \mathrm{~cm}^{-1}$, which can be ascribed to D and G bands that are designated to disordered and graphitic phases in carbon, respectively [38]. The intensity ratio of $\mathrm{D}$ and $\mathrm{G}$ band $\left(I_{\mathrm{D}} / I_{\mathrm{G}}\right)$, as an indication for the defects of structure in carbon, is shown for each sample (Table 1). The disordered and graphitic phases in carbon are both beneficial to the electrocatalytic ORR because they can provide active

Table 1

Summary of textual properties of the mesoporous carbon materials.

\begin{tabular}{lcccc}
\hline Sample & $S_{\text {BET }^{a}} / \mathrm{m}^{2} \mathrm{~g}^{-1}$ & $V_{\text {pore }^{b}} / \mathrm{cm}^{3} \mathrm{~g}^{-1}$ & $D_{\text {pore }^{c}} / \mathrm{nm}$ & $I_{\mathrm{D}} / I_{\mathrm{G}}$ \\
\hline MC & 666 & 0.698 & 5.4 & 1.42 \\
P-MC & 721 & 0.714 & 6.2 & 1.56 \\
P-MC-4 & 737 & 0.765 & 5.8 & 1.47 \\
P-MC-6 & 685 & 0.729 & 5.8 & 1.49 \\
P-MC-8 & 678 & 0.707 & 5.8 & 1.53 \\
\hline
\end{tabular}

a Specific surface area calculated using the BET method. b Pore volume determined from the relative pressure of $P / P_{0}=0.98$. ${ }^{c}$ Pore diameter obtained from the curve of pore size distribution. sites and high electrical conductivity, respectively. Remarkably, the $I_{\mathrm{D}} / I_{\mathrm{G}}$ is increased from 1.42 for MC to 1.56 for P-MC, implying that the presence of more defects in carbon material after the doping of P. The $I_{\mathrm{D}} / I_{\mathrm{G}}$ of P-MC-4 is lower than that of P-MC, indicating the higher degree of graphitization. It can be inferred the addition of iron endow this carbon material with high ORR activity for the high conductivity. The $I_{\mathrm{D}} / I_{\mathrm{G}}$ increases to 1.49 and 1.53 for P-MC- 6 and P-MC-8, respectively, which mainly due to the increasing defects derived from more introduction of P.

The surface chemistry properties of P-MC- 4 were studied by XPS measurements. The XPS survey spectrum reflects that P-MC-4 is consisted of element C, $\mathrm{O}$, and P (Fig. 3(b)). The fine C 1s XPS spectrum (Fig. 3(c)) centered at about 288.9, 286.7, 285.6 and $284.7 \mathrm{eV}$ indicates the existence of carbonxyl or ester groups, $\mathrm{C}-\mathrm{O}, \mathrm{C}-\mathrm{O}-\mathrm{P}$, and $\mathrm{C}-\mathrm{C}$ bonding, respectively [39]. Fitting of high-resolution $\mathrm{P} 2 p$ XPS spectrum demonstrates the existence of two types of $\mathrm{P}$ species, i.e., $\mathrm{P}-\mathrm{C}$ bonding $(132.7 \mathrm{eV})$ and P-O bonding (134.3 eV) in the carbons (Fig. 3(d)) [40]. XPS analysis confirms that the heteroatom $\mathrm{P}$ is successfully introduced into the framework of P-MC-4 catalyst. Quantitative XPS analysis indicates that $\mathrm{P}$ is present with 0.47 at $\%$, while 0.64 and 0.72 at\% in P-MC- 6 and P-MC-8, respectively. Notably, Fe species are absent in the carbon materials because Fe was removed by concentrated acid. Herein, Fe cannot be detected in 

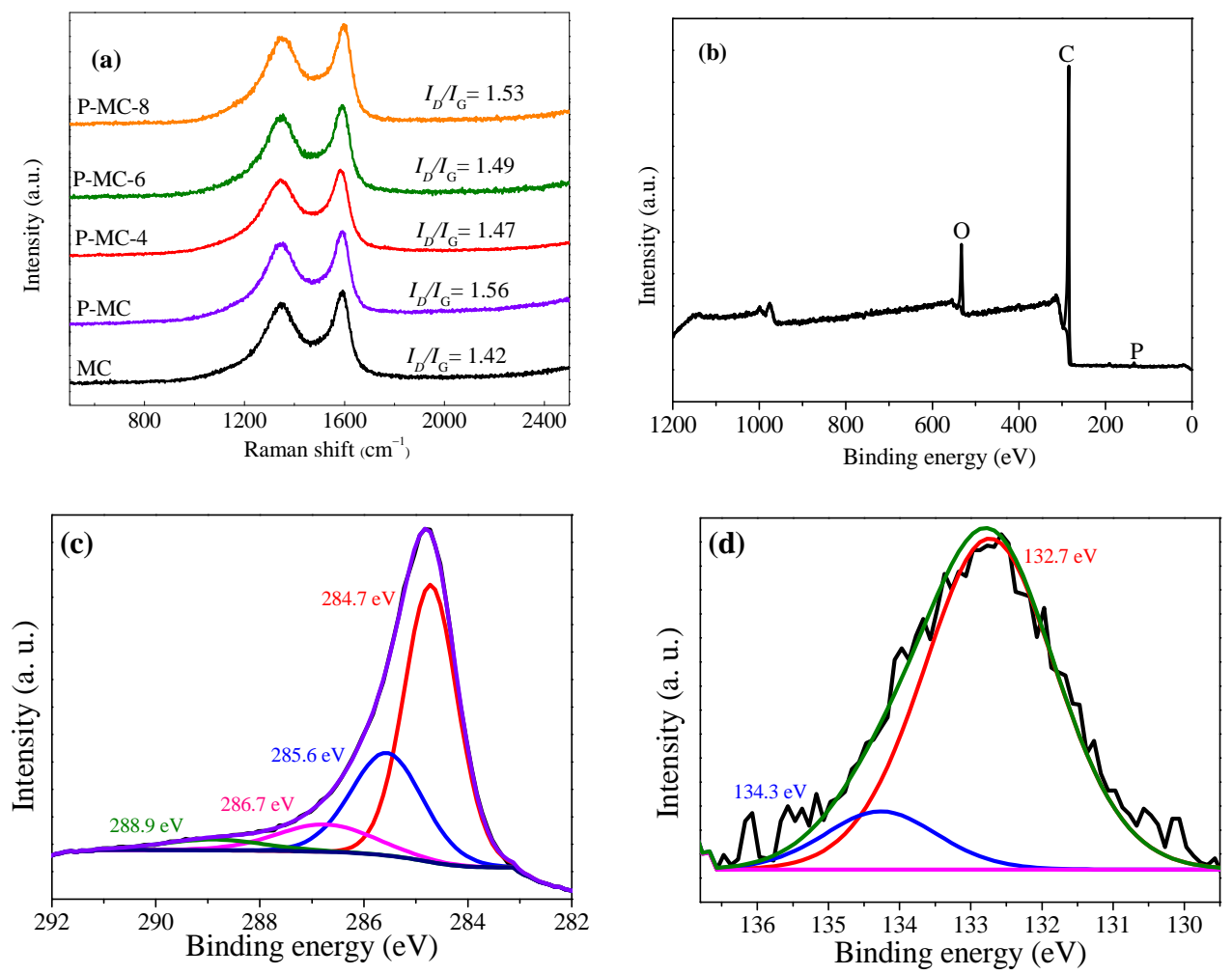

Fig. 3. (a) Raman spectra of MC, P-MC and P-MC- $x$ samples. The ratio of D-band to G-band $\left(I_{\mathrm{D}} / I_{\mathrm{G}}\right)$ is demonstrated for each sample. Survey XPS spectrum (b), high-resolution C $1 s$ (c) and P $2 p$ (d) XPS spectra of P-MC-4

the XPS measurements. The results indicate that HEDP can be served as a highly promising phosphorous source to afford the P-doped mesoporous carbons. The existence of organic functionalities in HEDP could be favorable for the molecular interactions among formaldehyde, surfactant molecules and phloroglucinol, thus introducing heteroatom P [27]. Additionally, the introduction amount of HEDP determines the doping amount of $\mathrm{P}$, which can greatly affect the catalytic activity of carbon materials.

The above results demonstrate that the introduction of heteroatom P can optimize the textural properties of carbon materials, which is considered to be beneficial for ORR as it increases the active sites. $\mathrm{FeCl}_{3}$, as the graphitization catalyst, can promote the formation of well-defined porous structure and conductivity of carbon materials, which can further facilitate the electron transfer and mass transportation during the ORR process. To study the catalytic performance of the P-doped mesoporous carbons for the ORR, the cyclic voltammograms (CVs) of the carbon materials with a scan rate of $20 \mathrm{mV} \mathrm{s}^{-1}$ in $\mathrm{O}_{2}$-saturated $0.1 \mathrm{~mol} / \mathrm{L} \mathrm{KOH}$ electrolyte were first performed. As demonstrated in Fig. 4(a), all samples possess a well-resolved catholic ORR peak, indicating the remarkable electrocatalytic performance for ORR. In comparison with the pure carbon, P-MC exhibits larger area under CV, indicating a larger active surface area for P-MC, in good accordance with the result obtained from the BET specific surface area. Additionally, the more positive peak potentials and stronger peak current density of P-MC manifest that the introduction of phosphorous into the framework of carbon materials can significantly facilitate the ORR process. Compared to P-MC, P-MC-4 shows an even better ORR performance, as evidenced by its more positive peak potential and stronger peak current density. It manifests the positive role of Fe species in facilitating the ORR performance. The RDE linear sweep voltammogram (LSV) recorded at a rotation speed of $1600 \mathrm{rpm}$ with a scan rate of 10 $\mathrm{mV} / \mathrm{s}$ is shown in Fig. 4(b). The distinct advantage with regard to the ORR limiting current density, half wave potential and onset potential is observed when introducing $\mathrm{P}$ into the carbon matrix. The onset potential and limiting current density of ORR on pure carbon is $0.86 \mathrm{~V}, 2.90 \mathrm{~mA} \mathrm{~cm}^{-2}$, respectively. Besides, an inefficient two-step ORR process is presented. Compared to the pure carbon material, the onset potential of P-MC increases positively to $0.89 \mathrm{~V}$ and further increases to $0.91 \mathrm{~V}$ for P-MC-4. Similarly, the limiting current density of P-MC-4 is $4.25 \mathrm{~mA}$ $\mathrm{cm}^{-2}$, which is much higher than that of $\mathrm{P}-\mathrm{MC}$ and $\mathrm{MC}$. The half-wave potential of the P-MC-4 presents a negative shift of only $\sim 37 \mathrm{mV}$ with respect to $\mathrm{Pt} / \mathrm{C}$, further indicating the higher ORR activity of P-MC-4 than that of P-MC and MC, which is comparable to commercial $\mathrm{Pt} / \mathrm{C}$ catalyst. It is reported that the P-doping induced charge redistribution is responsible for the ORR performance of carbon-based catalysts [36]. Besides, the addition of $\mathrm{FeCl}_{3}$ in the synthesis procedure can improve the porous structure and the degree of graphitization, which are attributable to the gas transportation and high conductivity, and thus favors the ORR activity.

To better understand the effect of doping amount of $\mathrm{P}$ on the 

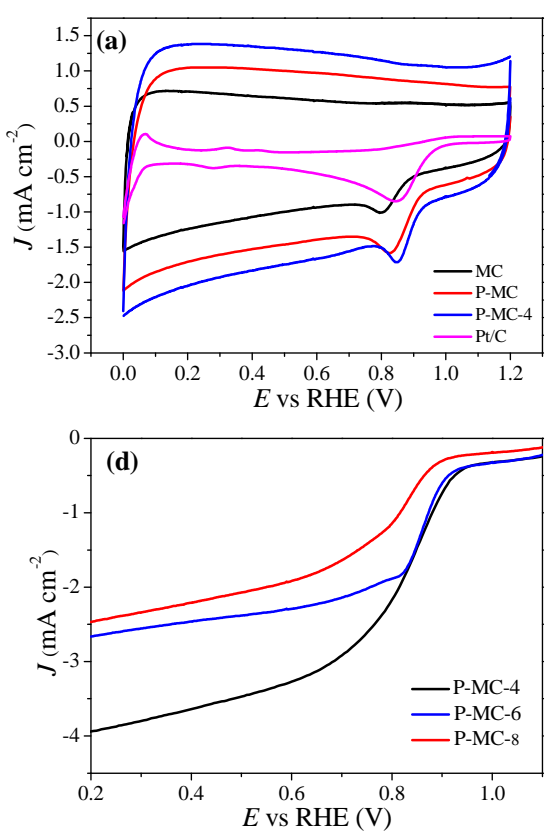
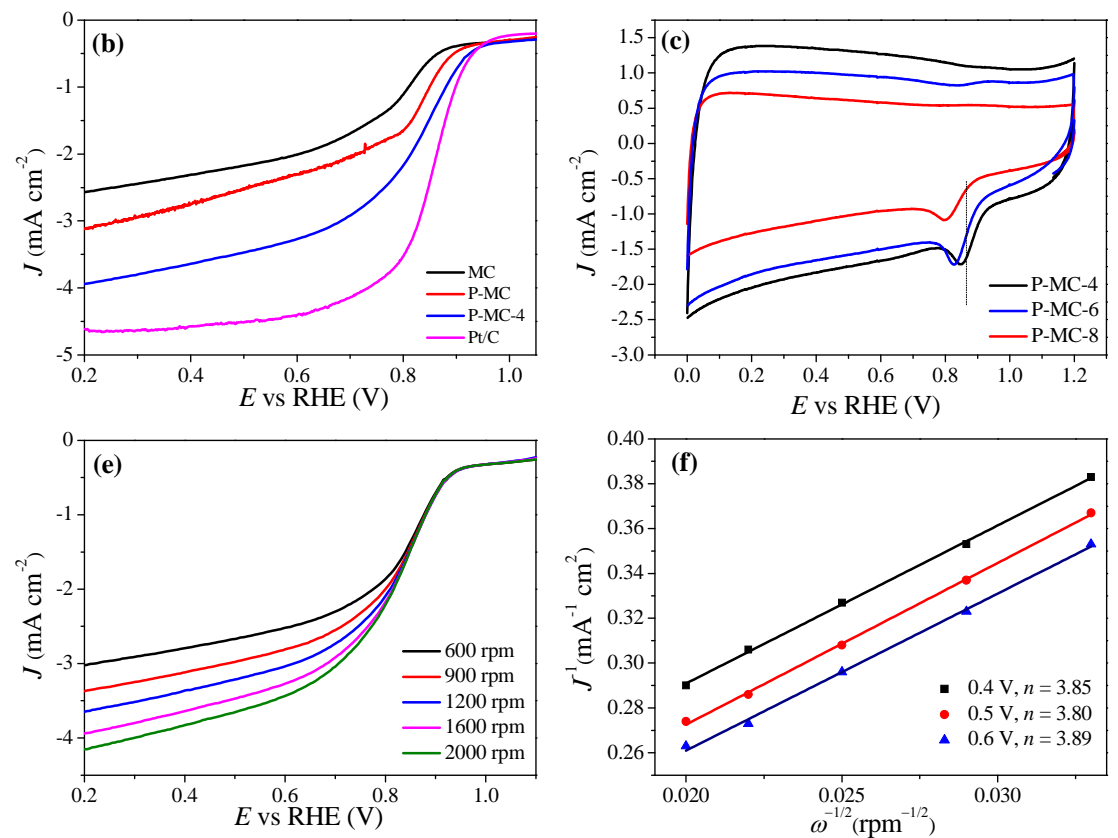

Fig. 4. (a) CVs of Pt/C and the synthesized samples in $\mathrm{O}_{2}$-saturated $0.1 \mathrm{M} \mathrm{KOH}$ at a scan rate of $20 \mathrm{mV} \mathrm{s}{ }^{-1}$. (b) LSV curves of Pt/C and the synthesized samples at a rotation rate of $1600 \mathrm{rpm}$ with a scan rate of $10 \mathrm{mVs}^{-1}$. (c) CVs of the P-MC- $x$ samples in $\mathrm{O}_{2}$-saturated $0.1 \mathrm{M} \mathrm{KOH}$ at a scan rate of $20 \mathrm{mV}$ $\mathrm{s}^{-1}$. (d) LSV curves of the P-MC- $x$ materials with a scan rate of $10 \mathrm{mV} \mathrm{s}{ }^{-1}$ at a rotation rate of $1600 \mathrm{rpm}$. (e) LSVs of ORR on P-MC-4 at different electrode rotating speeds in $\mathrm{O}_{2}$-saturated $0.1 \mathrm{M} \mathrm{KOH}$. (f) Koutecky-Levich plots of ORR on P-MC-4.

electrocatalytic ORR performance of the P-MC- $x$ catalyst, we compared the electrocatalytic performance of P-MC-4 with those of P-MC- 6 and P-MC-8 by CV and LSV. As shown in Fig. 4(c) and (d), with the increase of the doping amount of $P$, the ORR performance of the catalyst decreases. It is indicated that more dopant of $\mathrm{P}$ may disturb the structure of carbon materials, further hampering the enhancement of electrocatalytic performance. The results clearly show that the doping amount of $\mathrm{P}$ plays an important role in the electrocatalytic performance of the catalyst. Furthermore, the suitable doping amount of $\mathrm{P}$ in the framework of carbon materials can achieve the improved catalytic performance of mesoporous carbons. The polarization curves on P-MC-4 at various rotation rates from 600-2000 rpm for the ORR are shown in Fig. 4(e). The corresponding Koutecky-Levich plots at the potential range of 0.4-0.6 $\mathrm{V}$ exhibit high linearity (Fig. 4(f)). Additionally, the number of transferred electron determined from the slope of K-L plot is 3.85, 3.80 and 3.89 , respectively, which is similar to that of commercial Pt/C, suggesting a dominant $4 \mathrm{e}^{-}$pathway towards ORR for the case of P-MC-4.

Besides catalytic activity, the durability of catalyst is also an important parameter for metal-air batteries or fuel cells. The durabilities of commercial Pt/C and P-MC-4 catalysts were investigated using a chronoamperometric response method as observed in Fig. 5(d). Remarkably, the current of P-MC-4 shows a slow reduction, and a high relative current of $91.7 \%$ is kept over 12,000 s under a constant cathodic voltage of $0.6 \mathrm{~V}$. However, the Pt/C catalyst is observed for a rapid $21.4 \%$ loss of the current. This indicates that the P-MC-4 catalyst is more durable than the commercial Pt/C catalyst. Another crucial concern for the practical application of cathode materials in direct metha- nol fuel cells is methanol tolerance capacity. On this context, we tested the electrocatalytic selectivity of catalysts against the electro-oxidation of methanol $(0.5 \mathrm{~mol} / \mathrm{L})$. As shown in Fig. 5(a) and (b), no activity specific to methanol on P-MC-4 is observed where the characteristic peaks of ORR are maintained, implying the high selectivity towards ORR. On the contrary, commercial Pt/C catalyst (Fig. 5(c)) shows a prominent oxidation peak corresponding to methanol oxidation coupled with a negative shift of potential for ORR, indicating the poisoning of the catalyst. These results reveal our catalyst not only has an excellent stability, but also has higher catalytic selectivity toward ORR than that of $\mathrm{Pt} / \mathrm{C}$.

\section{Conclusions}

We employed the organophosphonic acid as the $\mathrm{P}$ source and phenolic resin as the carbon source to obtain the P-doped mesoporous carbons and investigated their catalytic performance toward ORR in alkaline electrolyte. It is found that the prepared catalyst exhibit a small amount of $\mathrm{P}$ doping coupled with well-defined wormhole-like pore structure and high surface area. With the addition of P, the electrocatalytic ORR activity improves significantly compared with the pristine mesoporous carbon materials. The introduction of a small amount of graphitization catalyst $\mathrm{FeCl}_{3}$ greatly improves the ORR performance. A synergistic contribution is needed from both the $\mathrm{P}$ doping and textural properties to attain high catalytic performance. The effect of the doping amount of $\mathrm{P}$ on catalytic performance was also studied, showing a decrease in activity with an increase in the doping amount of P. Notably, Fe is not present in the resultant materials due to the strong acid washing. 

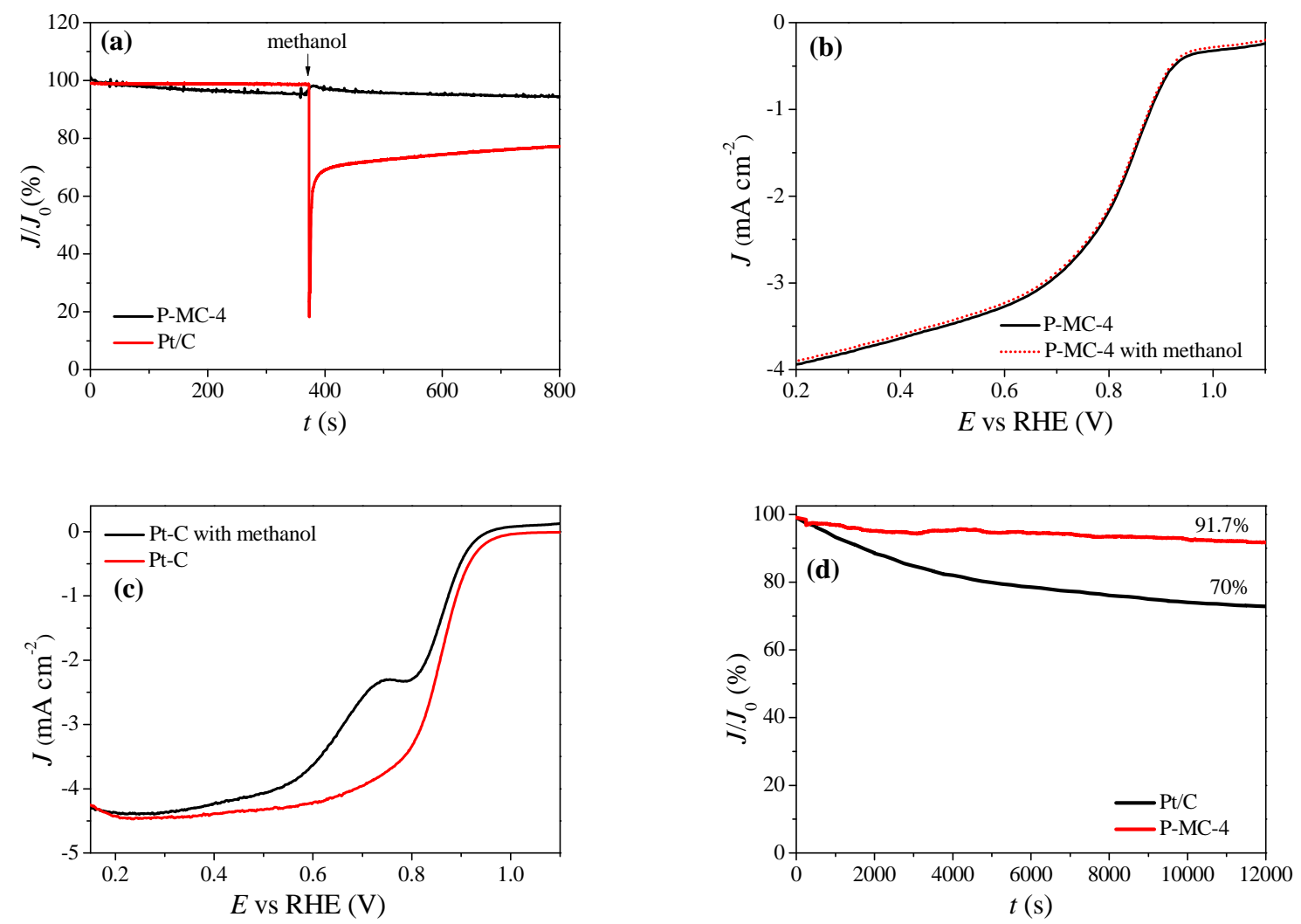

Fig. 5. (a) Chronoamperometric response curves of Pt/C and P-MC-4 in $\mathrm{O}_{2}$-saturated $0.1 \mathrm{~mol} / \mathrm{L} \mathrm{KOH}$ electrolyte with the addition of $3 \mathrm{~mol} / \mathrm{L} \mathrm{metha-}$ nol. LSV curves of P-MC-4 (b) and Pt/C (c) in an $\mathrm{O}_{2}$-saturated $0.1 \mathrm{~mol} / \mathrm{L} \mathrm{KOH}$ with the addition of $3 \mathrm{~mol} / \mathrm{L}$ methanol. (d) Durability measurement curves for P-MC-4 and Pt/C at $0.6 \mathrm{~V}$, scan rate: $50 \mathrm{mV} \mathrm{s}^{-1}$.

Therefore, the synthesized material is a true metal-free catalyst with outstanding catalytic performance. In addition to enhanced electrocatalytic performance, promotion in catalytic kinetics was also found, showing that P-MC-4 follows $\sim 4$ electron pathway in alkaline electrolyte for ORR. Moreover, the superior durability and immunity for methanol crossover than $\mathrm{Pt} / \mathrm{C}$ make these cost-effective mesoporous carbon catalysts a potential substitute to Pt-based catalysts in direct methanol fuel cells.

\section{Acknowledgments}

This work was supported by the National Natural Science Foundation of China $(21421001,21573115)$.

\section{References}

[1] J. Greeley, I. E. L. Stephens, A. S. Bondarenko, T. P. Johansson, H. A. Hansen, T. F. Jaramillo, J. Rossmeisl, I. Chorkendorff, J. K. Nørskov, Nat. Chem., 2009, 1, 552-556.

[2] X. J. Tang, D. H. Fang, L. J. Qu, D. Y. Xu, X. P. Qin, B. W. Qin, W. Song, Z. G. Shao, B. L. Yi, Chin. J. Catal., 2019, 40, 504-514.

[3] V. R. Stamenkovic, B. Fowler, B. S. Mun, G. Wang, P. N. Ross, C. A. Lucas, N. M. Markovi, Science, 2007, 315, 493-497.

[4] B. Lim, M. Jiang, P. H. C. Camargo, E. C. Cho, J. Tao, X. Lu, Y. Zhu, Y. Xia, Science, 2009, 324, 1302-1305.
[5] V. R. Stamenkovic, B. S. Mun, M. Arenz, K. J. J. Mayrhofer, C. A. Lucas, G. Wang, P. N. Ross, N. M. Markovic, Nature Mater., 2007, 6, 241-247.

[6] G. Wu, K. L. More, C. M. Johnston, P. Zelenay, Science, 2011, 332, 443-447.

[7] Y. Nie, L. Li, Z. D. Wei, Chem. Soc. Rev., 2015, 44, 2168-2201.

[8] S. J. Guo, S. Zhang, S. H. Sun, Angew. Chem. Int. Ed., 2013, 52, 8526-8544.

[9] S. Y. Wang, D. S. Yu, L. M. Dai, J. Am. Chem. Soc., 2011, 133, 5182-5185.

[10] X. H. Guo, Y. P. Zhu, T. Y. Ma, J. Energy Chem., 2017, 26, 1107-1116.

[11] D. M. Feng, Y. Sun, Z. Q. Liu, Y. P. Zhu, T. Y. Ma, J. Nanosci. Nanotechnol., 2019, 19, 3079-3096.

[12] L. Liu, Y. P. Zhu, M. Su, Z. Y. Yuan, ChemCatChem, 2015, 7, 2765-2787.

[13] H. Li, Y. Sun, Z. Y. Yuan, Y. P. Zhu, T. Y. Ma, Angew. Chem. Int. Ed., 2018, 57, 3222-3227.

[14] H. Ge, L. Cui, Z. Sun, D. Wang, S. Nie, S. Zhu, B. Matthews, G. Wu, X. M. Song, T. Y. Ma, J. Mater. Chem. A, 2018, 6, 22053-22061.

[15] J. J. Zhu, Q. X. Lai, Y. X. Zhao, J. Zhong, Y. Y. Liang, Angew. Chem. Int. Ed., 2018, 39, 1453-1462.

[16] H. Zhao, Z. Y. Yuan, Catal. Sci. Technol., 2017, 7, 330-347.

[17] J. H. Tong, W. Y. Li, W. H. Wang, Y. L. Li, T. Li, Q. Zhang, H. Y. Fan, Chin. J. Catal., 2018, 39, 1138-1145.

[18] J. T. Ren, Z. Y. Yuan, ChemCatChem, 2018, 10, 3260-3268.

[19] Y. J. Song, J. T. Ren, G. Yuan, Y. Yao, X. Liu, Z. Y. Yuan, J. Energy Chem., 2019, 38, 68-77.

[20] G. P. Liu, B. Wang, L. Xu, P. H. Ding, P. F. Zhang, J. X. Xia, H. M. Li, J. C. 


\title{
Graphical Abstract
}

Chin. J. Catal., 2019, 40: 1366-1374 doi: S1872-2067(19)63363-2

P-doped mesoporous carbons for high-efficiency electrocatalytic oxygen reduction

Hui Zhao, Zhong-Pan Hu, Yun-Pei Zhu, Li Ge, Zhong-Yong Yuan* Nankai University

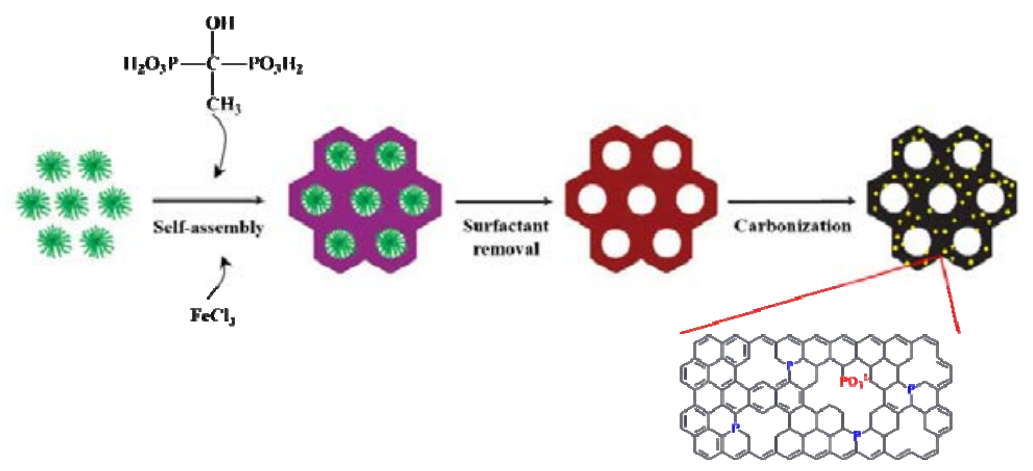

P-doped mesoporous carbons were synthesized by a soft-templating method with the use of organophosphonic acid as the P source and iron species as a graphitization catalyst, exhibiting superior catalytic activity towards ORR in alkaline media.

Qian, Chin. J. Catal., 2018, 39, 790-799.

[21] J. T. Ren, G. G. Yuan, L. Chen, C. C. Weng, Z. Y. Yuan, ACS Sustainable Chem. Eng., 2018, 6, 9793-9803.

[22] C. Z. Guo, W. L. Liao, L. T. Sun, C. G. Chen, Int. J. Electrochem. Sci., 2015, 10, 2467-2477.

[23] T. Y. Yang, J. Liu, R. F. Zhou, Z. G. Chen, H. Y. Xu, S. Z. Qiao, M. J. Monteiro, J. Mater. Chem. A, 2014, 2, 18139-18146.

[24] J. Zhang, S. Y. Wu, X. Chen, M. Pan, S. C. Mu, J. Power Sources, 2014, 271, 522-529.

[25] Z. W. Liu, F. Peng, H. J. Wang, H. Yu, W. X. Zheng, J. Yang, Angew. Chem. Int. Ed., 2011, 50, 3257-3261.

[26] X. Sun, J. Y. Xu, Y. X. Ding, B. S. Zhang, Z. B. Feng, D. S. Su, ChemSusChem, 2015, 8, 2872-2876.

[27] Y. P. Zhu, Y. L. Liu, Y. P. Liu, T. Z. Ren, T. H. Chen, Z. Y. Yuan, ChemCatChem, 2015, 7, 2903-2909.

[28] J. Wu, X. J. Zheng, C. Jin, J. H. Tian, R. Z. Yang, Carbon, 2015, 92, 327-338.

[29] X. Gong, S. S. Liu, C. Y. Ouyang, P. Strasser, R. Z. Yang, ACS Catal., 2015, 5, 920-927.

[30] Y. P. Zhu, Y. L. Liu, Y. P. Liu, T. Z. Ren, G. H. Du, T. H. Chen, Z. Y. Yu- an, J. Mater. Chem. A, 2015, 3, 11725-11729.

[31] H. Zhao, Y. P. Zhu, Z. Y. Yuan, Eur. J. Inorg. Chem., 2016, 2016, 1916-1923.

[32] D. S. Yang, D. Bhattacharjya, S. Inamdar, J. Park, J. S. Yu, J. Am. Chem. Soc., 2012, 134, 16127-16130.

[33] L. Liu, Q. F. Deng, T. Y. Ma, X. Z. Lin, X. X. Hou, Y. P. Liu, Z. Y. Yuan, J. Mater. Chem., 2011, 21, 16001-16009.

[34] Y. Xia, R. Makaya, Adv. Mater., 2004, 16, 1553-1558.

[35] G. Q. Sun, L. H. Zhou, J. X. Li, J. Tang, Y. Wang, RSC Adv., 2015, 5, 71980-71987.

[36] F. Razmjooei, K. P. Singh, E. J. Bae, J. S. Yu, J. Mater. Chem. A, 2015, 3, 11031-11039.

[37] C. Z. Zhu, H. Li, S. F. Fu, D. Du, Y. H. Lin, Chem. Soc. Rev., 2016, 45, 517-531.

[38] K. N. Kudin, B. Ozbas, H. C. Schniepp, R. K. Prud'homme, I. A. Aksay, R. Car, Nano Lett., 2008, 8, 36-41.

[39] A. M. Puziy, O. I. Poddubnaya, R. P. Socha, J. Gurgul, M. Wisniewski, Carbon, 2008, 46, 2113-2123.

[40] L. F. Chen, Z. H. Huang, H. W. Liang, H. L. Gao, S. H. Yu, Adv. Funct. Mater., 2014, 24, 5104-5111.

\section{磷掺杂的介孔碳材料作为高效氧还原电催化剂}

\author{
赵 挥 ${ }^{\mathrm{a}, \mathrm{b}}$, 胡忠攀 $\mathrm{a,b}$, 朱运培 $\mathrm{a}, \mathrm{b}$, 葛 丽 ${ }^{\mathrm{a}, \mathrm{b}}$, 袁忠勇 ${ }^{\mathrm{a}, \mathrm{b}, *}$ \\ $\mathrm{a}$ 南开大学材料科学与工程学院, 国家新材料研究院, 天津 300350 \\ ${ }^{\mathrm{b}}$ 天津化学化工协同创新中心, 先进能源材料化学教育部重点实验室, 天津 300071
}

摘要: 化学改性的碳材料由于其可控的理化性能、可设计的微纳结构以及优良的稳定性, 在可再生能源储存和转换领域得 到了极大的关注. 将杂原子例如 $N, P, B$ 和 S掺杂到碳材料的骨架结构可以显著改善其电催化活性, 这是因为杂原子掺杂可 以打破相邻碳原子的电中性, 创造活性位点, 从而有利于氧气分子的吸附和氧还原反应的进行. 早期报道比较多的是氮掺 杂的碳材料, 后续的研究发现, 与氮掺杂相比, 磷掺杂能够更有效地对碳的结构和性能进行改性, 因为磷原子比氮原子具有 更大的共价半径和更低的电负性, 磷掺杂的碳材料也表现出更为优异的催化活性. 此外, 氧还原反应活性极大地依赖于碳 材料的结构性质诸如导电性, 稳定性和活性位点的分散程度等. 基于这种考虑, 构建具有高比表面积以及发达孔隙率的多 
孔碳材料有利于对活性位点的充分利用, 并改善催化反应过程的物质传输. 但是制备磷掺杂多孔碳材料的方法一般都比 较复杂且危险, 为此, 本课题组发展了一种有机一有机自组装的软模板法, 以有机膦酸为磷源制备了磷掺杂的介孔碳材料用 于电催化氧还原反应,所得到的材料具有较高的磷掺杂率和较大的比表面积, 然而, 该催化剂的表观活性与商业 $\mathrm{Pt} / \mathrm{C}$ 相比仍 有很大差距, 而且磷掺杂量对介孔碳材料结构和活性的影响也不甚清楚. 基于此, 本文采用有机膦酸羟基乙叉二膦酸 (HEDP)为磷源, 酚醛树脂为碳源, 并加入适量的铁物种制备得到了介观结构良好的碳材料, 其中, 制备过程中铁物种可以 作为石墨化催化剂, 增强材料的石墨化程度, 随后的酸洗将其去除, 所得碳材料比表面积大, 孔径分布窄, 导电性能良好. 此外, 进一步探讨了磷的掺杂量对电催化活性的影响.

XRD和TEM结果表明, 适量磷掺杂所制备的催化剂(P-MC-4)具有有序的蠕虫状孔结构; EDS图谱表明, 磷原子已经均 匀的掺杂到碳材料的骨架结构中; $\mathrm{N}_{2}$ 吸附-脱附测试表明, 适量的磷掺杂有利于改善碳材料的孔性, 较高的磷掺杂量会导致 碳材料较差的织构性质. Raman光谱结果表明, 铁物种的引入增强了碳材料的石墨化程度并提高了导电性, 而磷掺杂导致 其缺陷位点增多, 磷掺杂量越多, 缺陷也就越多. 我们进一步研究了 P-MC-4的表面化学性质, XPS结果表明, 磷掺杂量为 $0.47 \mathrm{at} \%$ 的HEDP可以作为一种极有潜力的磷源来合成磷掺杂的介孔碳材料, 此外, HEDP的引入量决定了磷的掺杂量, 也 极大的影响了碳材料的催化活性. 电催化反应测试表明, P-MC-4的氧还原活性与商业Pt/C是可比的, 其遵循的是 4 电子的 反应路径, 而且其抗甲醇氧化能力和稳定性优于 $\mathrm{Pt} / \mathrm{C}$. 其原因主要归结于以下几点: (1)磷掺杂提供了催化反应的活性位点, 磷能够改善碳材料的给电子能力, 进而提高电催化活性; 磷的掺杂量极大的影响了碳材料的结构性质并进一步影响催化 活性, 适量的磷掺杂能够显著提升碳材料的电催化活性; (2)加入铁物种作为石墨化试剂, 能显著提高碳材料的石墨化程度, 从而增大其导电性, 有利于催化反应中的电子传输; (3)相比微孔和大孔介孔结构更有利于活性位点的暴露和物质传输, 而 且P-MC-4具有相对有序的孔结构和较高的比表面积, 也有助于催化反应中的介质传输. 值得注意的是, 最终得到的催化剂 并不含有铁, 所以该材料是一个无金属的催化活性良好的电催化剂, 有望替代Pt/C催化剂应用于燃料电池中.

关键词: 磷掺杂; 介孔碳; 电催化剂; 氧还原反应

收稿日期: 2019-03-17. 接受日期: 2019-04-01. 出版日期: 2019-09-05.

*通讯联系人. 电话: (022)23509610; 电子信箱: zyyuan@nankai.edu.cn

基金来源：国家自然科学基金(21421001, 21573115).

本文的电子版全文由Elsevier出版社在ScienceDirect上出版(http://www.sciencedirect.com/science/journal/18722067). 